\title{
Dairy Based Farming: Economic Analysis for Viable Livelihood Opportunity for Jhum Practicing Tribal People of Mizoram State
}

\author{
Lalrin Sangpuii* and Ravinder Malhotra
}

Division of Dairy Economics, Statistics \& Management, National Dairy Research Institute, Karnal, Haryana (132 001), India

\section{Article History}

Manuscript No. AR1538b

Received in $15^{\text {th }}$ February, 2016

Received in revised form $29^{\text {th }}$ May, 2016

Accepted in final form $6^{\text {th }}$ June, 2016

\section{Correspondence to}

"E-mail: mapuiibh@yahoo.com

\section{Keywords}

Jhum cultivation, dairy-based farming, farm efficiency, employment potential

\begin{abstract}
Jhum cultivation in North Eastern Region of India is traditionally practiced by local tribes. This practice accounts almost $84 \%$ of total shifting cultivation area of India. Of late, this system becomes a serious threat to the livelihoods opportunity and environmental security in the region. Keeping this in view, the present study was conducted to explore the contribution of crops towards income generation both under Jhum condition and integrated crops-cattle farming condition in three districts of Mizoram in the year 2014-15. Usual farm management techniques were applied to assess the profitability. Cost of crop cultivation in Jhum was estimated to be ₹ 23778 $\mathrm{ha}^{-1}$ while in case of integrated farming it was worked out to be ₹ $38886 \mathrm{ha}^{-1}$. The income generated from crop under dairy-based farming ( $₹ 41906 \mathrm{ha}^{-1}$ ) was found to be much higher than the income obtained from crops in Jhum farming ( $₹ 23581 \mathrm{ha}^{-1}$ ) implying that dairy-based farming was more profitable compared to Jhum farming. Jhum could be profitable if family labour engagement was the practice. The ha- ${ }^{-1}$ cost of cattle maintenance was found to be ₹ 66711 while the gross return was estimated to be ₹ 72332. The B-C ratio for dairy-based farm was found to be more than 1(one) indicating the profitability of this type of farming. In addition, the integrated cropscattle farming had higher potentiality to afford farm employment. It is, thus, suggested to provide necessary support to make this system more adopted by the tribal people of Mizoram for its economic viability.
\end{abstract}

\section{Introduction}

Jhum cultivation or shifting cultivation is a dominant landuse practice of North-Eastern Region (NER) of India and is mostly practiced in the tribal dominated hilly areas. The people involved in this practice are known as 'Jhumiyas' (Choudhury, 2004). In this type of cultivation, the forest area is cleaned, burnt and a variety of crops are cultivated in the slope of the hills. Once the productivity of the Jhum is reduced, the land is abandoned and new area is prepared for cultivation. The population explosion and increased demand for cultivable land have resulted in reduction of Jhum cultivation cycle. The Jhum cycle in most areas, which used to be $10-15$ years earlier is now reducing to $2-3$ years only (Tripathi and Barik, 2003). This leads to severe soil loss due to erosion, deforestation causing serious environmental degradation and ecological imbalance (Satapathy and Bujarbaruah, 2006). Area under shifting cultivation in the entire NER is around 1.99 mha which occupies $5.51 \%$ of the total geographical area. This accounts nearly $83.73 \%$ of the total area under shifting cultivation in India (Patel et al., 2013; Mandal, 2011). The rate of land degradation stands at $34.7 \%$ which is almost two fold more than the national average of $20.2 \%$ (Patel et al., 2013).

Mizoram is also known for its shifting cultivation and it affects $8.98 \%$ of the total geographical area of the State. Jhum cultivation is practised in 40089 ha of land which accounts about $38.64 \%$ of net sown area (GoM, 2013). In this context, organic farming system is looked upon as one of the means to remedy these problems (Kumaresan et al., 2008). Besides, the milk and meat from the dairy industry are very popular and the demand for manure is constantly increasing. As a matter of fact, the State has been declared as Organic State. So in order to promote "settled cultivation" in place of "shifting cultivation", livestock rearing, especially dairying could play a very important role for manure of cattle is also used to enrich the soil fertility. Further, cow, buffaloes, poultry, goats and pigs are not only the source of organic manures but it also provides additional income to the farming community in general and resource in particular (Kumaresan et al., 2009).

In view of above, the present study aims to analyze costs, returns and employment opportunity from both the systems 
under Jhum condition and integrated crop-cattle farming conditions to have an idea for comparison, which, in turn, will promote the economically most viable and sustainable system in the existing socio-eco-ecological constraints.

\section{Materials and Methods}

\subsection{Study sites}

The study was conducted in Mizoram State. Out of the eight districts in Mizoram, the three districts viz. Aizawl, Kolasib and Champhai districts were selected as these districts have higher net sown area, higher bovine population and milk production comparing to other districts of the state. From each of the three districts, two blocks and from each block two villages and from each village sample of farmers were randomly selected make total respondents of 120 households.

\subsection{Method of data collection}

The primary data was collected in structured schedule through personal interview method on various aspects of crops and dairy enterprises from selected households for two seasons i.e. Rainy season (June-August) and Dry season (MarchMay) during the year 2014-15. A sample of 120 households comprising $60 \mathrm{Jhum}$ farmers and 60 integrated crops-dairy farmers were selected.

\subsection{Costs and returns concept}

The data was subjected to tabular analysis for estimating costs and returns as well as employment generation from crop and cattle enterprises. Cost categories below was considered to study both crop and cattle enterprises. The crops considered

\begin{tabular}{|c|c|c|}
\hline Fixed costs & & $\begin{array}{l}\text { Fixed costs do not vary with the level } \\
\text { of output and remain unchanged over a } \\
\text { short period of time. The various com- } \\
\text { ponents of fixed costs are land revenue, } \\
\text { rent paid for leased-in land, rental } \\
\text { value of owned land depreciation and } \\
\text { interest on fixed capital. }\end{array}$ \\
\hline Variable costs & $=$ & $\begin{array}{l}\text { Variable costs are those costs, which are } \\
\text { incurred on the variable factors of pro- } \\
\text { duction and can be altered in the short } \\
\text { run. Variable costs includes seed cost, } \\
\text { manures and fertilizers cost, feed and } \\
\text { fodder cost, labour cost and veterinary } \\
\text { and miscellaneous expenditure, etc. }\end{array}$ \\
\hline Total cost & $=$ & Total variable costs + Total fixed costs \\
\hline Gross return & $=$ & Quantity of output $\times$ Market price of output \\
\hline $\begin{array}{l}\text { Gross margin } \\
\text { (Farm operat- } \\
\text { ing income) }\end{array}$ & $=$ & Gross return - Variable cost \\
\hline Net return & $=$ & Gross return - Total cost \\
\hline
\end{tabular}

under the study were paddy, maize, colocasia, chow-chow and pumpkin as these are the major crops grown in the study area. In order to find out the cost of crop cultivation, the various expenses incurred on each crop was worked out individually and then all the expenses from different crops were added together. Likewise, the returns obtained from various crops were obtained by working out for each individual crop and then added all the returns from various crops.

\section{Results and Discussion}

\subsection{Costs of crop cultivation}

Table 1 revealed that the average total cost of cultivation was ₹ 38886 and 23778 ha $^{-1}$ under dairy-based and Jhum farming respectively, indicating that higher investment has been made

Table 1: Estimation of costs of crop cultivation $\left(₹ \mathrm{ha}^{-1}\right)$ in jhum and dairy based farms

\begin{tabular}{|c|c|c|}
\hline Particulars & Jhum farm & Dairy-based farm \\
\hline \multicolumn{3}{|l|}{ Variable costs } \\
\hline Human labour & $\begin{array}{r}6867.27 \\
(28.88)\end{array}$ & $\begin{array}{c}11759.92 \\
(30.24)\end{array}$ \\
\hline Seed & $\begin{array}{r}2606.18 \\
(10.96)\end{array}$ & $\begin{array}{c}3860.05 \\
(9.93)\end{array}$ \\
\hline FYM & $\begin{array}{c}2001.09 \\
(8.42)\end{array}$ & $\begin{array}{r}6933.43 \\
(17.83)\end{array}$ \\
\hline $\begin{array}{l}\text { Chemical fertilizers } \\
\text { and pesticides }\end{array}$ & $\begin{array}{c}1541.37 \\
(6.48)\end{array}$ & $\begin{array}{c}1202.80 \\
(3.09)\end{array}$ \\
\hline $\begin{array}{l}\text { Interest on working } \\
\text { capital }\end{array}$ & $\begin{array}{c}1132.16 \\
(4.76)\end{array}$ & $\begin{array}{c}1515.74 \\
(3.90)\end{array}$ \\
\hline Total variable costs & $\begin{array}{c}14148.07 \\
(59.50)\end{array}$ & $\begin{array}{c}25271.93 \\
(64.99)\end{array}$ \\
\hline \multicolumn{3}{|l|}{ Fixed costs } \\
\hline Land revenue & $\begin{array}{l}134.87 \\
(0.57)\end{array}$ & $\begin{array}{c}481.1189 \\
(1.24)\end{array}$ \\
\hline Depreciation & $\begin{array}{r}358.11 \\
(1.51)\end{array}$ & $\begin{array}{r}641.72 \\
(1.65)\end{array}$ \\
\hline $\begin{array}{l}\text { Rent paid for } \\
\text { leased-in land }\end{array}$ & 0.00 & 0.00 \\
\hline $\begin{array}{l}\text { Interest on value of } \\
\text { owned capital assets } \\
\text { (excluding land) }\end{array}$ & $\begin{array}{r}199.33 \\
(0.84)\end{array}$ & $\begin{array}{r}289.09 \\
(0.74)\end{array}$ \\
\hline $\begin{array}{l}\text { Rental value of } \\
\text { owned land }\end{array}$ & $\begin{array}{r}8937.99 \\
(37.59)\end{array}$ & $\begin{array}{c}12201.86 \\
(31.38)\end{array}$ \\
\hline Total fixed costs & $\begin{array}{c}9630.31 \\
(40.50)\end{array}$ & $\begin{array}{c}13613.80 \\
(35.01)\end{array}$ \\
\hline Total cost & $\begin{array}{c}23778.37 \\
\quad(100)\end{array}$ & $\begin{array}{c}38885.73 \\
\quad(100)\end{array}$ \\
\hline
\end{tabular}

Note: Figures in parentheses are percentage to total cost 
on dairy-based farms in the study area. The share of variable costs to total costs was found to be much higher than fixed costs which were worked out to be $65 \%$ for integrated cropcattle farm and $60 \%$ for Jhum farm. This was largely attributed to high cost of labour and having converted family labour to cost at prevailing market price rate. The share of human labour cost to total cost was worked out to be $30 \%$ and $29 \%$ under dairy-based farm and Jhum farm, respectively. The total fixed costs accounted $41 \%$ and $35 \%$ under Jhum and integrated cropcattle farming conditions. Among the various components of fixed costs, rental value of owned land was the most important component as it shared $38 \%$ and $32 \%$ respectively for Jhum and dairy-based farms. This result corroborates with the finding of Singh and Dhillon (2015) who also reported that labour cost was the most important variable item as it shared $24.33 \%$ and rental value of owned land shared $43.02 \%$ of the total cost of ginger cultivation in Himachal Pradesh.

\subsection{Costs of cattle maintenance}

Only crossbred and indigenous types of cattle were found in the study area. It has also been estimated that in a hectare of land, there were around 18 numbers of indigenous and 10 numbers of crossbred cattle. The animal ${ }^{-1}$ and ha ${ }^{-1}$ costs of cattle farming under dairy-based farm was also analysed and is presented in Table 2. The animal ${ }^{-1}$ maintenance cost of cattle was estimated to be ₹ 10359 whereas in terms of ha $^{-1}$ it was found to be ₹

Table 2: Costs of maintenance of cattle (per animal and per ha)

\begin{tabular}{|c|c|c|}
\hline Particulars & Cattle $\left(₹\right.$ animal $\left.^{-1}\right)$ & Cattle (₹ ha-1) \\
\hline \multicolumn{3}{|l|}{ Variable costs } \\
\hline Green fodder & $2763.90(26.68)$ & $17799.52(26.68)$ \\
\hline Dry fodder & $247.41(2.39)$ & $1593.32(2.39)$ \\
\hline Concentrate & $3273.13(31.60)$ & $21078.96(31.60)$ \\
\hline Total feed cost & $6284.44(60.67)$ & $40471.79(60.67)$ \\
\hline Human labour & $3637.41(35.11)$ & $23424.92(35.11)$ \\
\hline $\begin{array}{l}\text { Veterinary } \\
\text { expenses }\end{array}$ & $44.46(0.43)$ & $286.32(0.43)$ \\
\hline $\begin{array}{l}\text { Miscellaneous } \\
\text { expenses }\end{array}$ & $156.66(1.51)$ & $1008.89(1.51)$ \\
\hline $\begin{array}{l}\text { Total variable } \\
\text { costs }\end{array}$ & $10122.97(97.72)$ & $65191.93(97.72)$ \\
\hline \multicolumn{3}{|l|}{ Fixed costs } \\
\hline $\begin{array}{l}\text { Interest on fixed } \\
\text { capital }\end{array}$ & $97.33(0.94)$ & $626.81(0.94)$ \\
\hline Depreciation & $138.61(1.34)$ & 892.65 (1.34) \\
\hline Total fixed costs & $235.94(2.28)$ & $1519.45(2.28)$ \\
\hline Total cost & $10358.91(100)$ & $66711.38(100)$ \\
\hline
\end{tabular}

Note: Figures in parentheses are percentage to total cost
66711. Among the various variable cost components, feed cost was the most important cost as it shared around $60 \%$ of the total cost which was lower than $78.28 \%$ as reported by Michael et al. (2012) in Nagaland, $62.08 \%$ as reported by Singh and Agarwal (2007) in Manipur and $80.57 \%$ by Singh and Chauhan (2015) in Meghalaya state. The expenditure on concentrate constituted the major feed cost which constituted $32 \%$ of the gross cost. The overall labour cost and veterinary and miscellaneous expenses accounted for $35 \%$ and $2 \%$ of the gross cost, respectively. The component wise break up of cost of cattle maintenance indicated that the contribution of variable cost to the gross cost $(97.72 \%)$ was much higher than the contribution of fixed costs $(2.28 \%)$. This may be due to the fact that almost all the cattle sheds were of kaccha type and moreover no mechanized equipments were used by the farmers in the study area.

\subsection{Returns from farming}

Gross returns, gross margin and net return per hectare of crop and cattle farming have been also presented in Table 3. The total average gross income realized by dairy-based farms ( $₹ 114238$ $h^{-1}$ ) was comparatively much higher than the income realized by the farms under Jhum condition (₹ $23581 \mathrm{ha}^{-1}$ ). Average net income for Jhum farms was found to be negative and the loss in regard to this income measures ₹ 197 ha $^{-1}$ while it was

\begin{tabular}{lcccc}
\hline \multicolumn{5}{l}{ Table 3: Returns from jhum and dairy-based farms (₹ ha-1 $)$} \\
\hline Particulars & $\begin{array}{l}\text { Jhum } \\
\text { farm }\end{array}$ & \multicolumn{3}{c}{ Dairy-based farm } \\
\cline { 2 - 5 } & Crop & Crop & Cattle & Total \\
\hline $\begin{array}{l}\text { Value of } \\
\text { main product }\end{array}$ & 22769.83 & 39541.96 & 71728.20 & 111270.16 \\
$\begin{array}{l}\text { Value of by- } \\
\text { product }\end{array}$ & 811.18 & 2363.64 & 603.81 & 2967.45 \\
$\begin{array}{l}\text { Gross return } \\
\text { Gross margin }\end{array}$ & 23581.01 & 41905.59 & 72332.02 & 114237.61 \\
$\begin{array}{l}\text { (Farm } \\
\text { operating }\end{array}$ & & 16633.67 & 7140.09 & 23773.76 \\
income) & & & & \\
Net return & -197.36 & 3019.86 & 5620.64 & 8640.50 \\
B:C & 0.99 & 1.08 & 1.08 & 1.08 \\
\hline
\end{tabular}

positive for integrated crops-cattle farms. The negative income for the former farms, thus, suggested that crop production was slightly more profitable for those practicing integrated cropscattle farming. However, the above results reveal that although net income was negative for Jhum farms, when family labour charges were subtracted from gross costs, income from crops becomes positive for all the farmers. Navadkar et al. (2012) 
reported that in Ahmednagar district of Maharashtra the ha-1 cost of and return from maize was worked out to be ₹ 40624.57 and ₹ 43154.44, respectively. The findings of Larka et al. (2014) also reported that the average cost of paddy cultivation in Dantewada district of Chhattisgarh was estimated to be ₹ $13533.63 \mathrm{ha}^{-1}$ while the average net income was observed to be ₹ $33169.87 \mathrm{ha}^{-1}$. The analysis also shows that Benefit-Cost (B-C) ratio was found to be greater than 1(one) for dairy-based farm indicating that this type of farming is a profitable business in the study area. In case of Jhum farm it was found to be less than 1 (one) and this loss could be compensated through the application of family labours.

\subsection{Employment generation}

The employment potential of crops cultivation under Jhum condition indicated engagement of nearly 171 mandays of labour ha ${ }^{-1}$ year $^{-1}$ (Table 4). It was found that the engagement of labor in crops cultivation under integrated crops-cattle farming was to the tune of 192 mandays ( $44 \%$ of total labour days), while that of cattle rearing, it was 246 mandays ( $56 \%$ of total labour days). This shows that the integrated farming provided a total employment of 438 mandays ha $^{-1}$ year $^{-1}$ indicating that

Table 4: Human labour employment in farming (mandays ha $^{-1}$ year $^{-1}$ )

\begin{tabular}{lcc}
\hline Particulars & $\begin{array}{c}\text { Under jhum } \\
\text { condition }\end{array}$ & $\begin{array}{c}\text { Under integrat- } \\
\text { ed crop-cattle } \\
\text { condition }\end{array}$ \\
\hline Crop cultivation & & \\
\cline { 1 - 2 } Hired labour & $49(28.65)$ & $67(15.30)$ \\
Owned labour & $122(71.35)$ & $125(28.54)$ \\
Total labour & $171(100)$ & $192(43.84)$ \\
Cattle rearing & & \\
\cline { 1 - 2 } Hired labour & - & $107(24.43)$ \\
Owned labour & - & $139(31.74)$ \\
Total labour & - & $246(56.16)$ \\
Total labour utilisation & & \\
\cline { 1 - 2 } Hired labour & $49(28.65)$ & $174(39.73)$ \\
Owned labour & $122(71.35)$ & $264(60.72)$ \\
Total labour & $171(100)$ & $438(100)$ \\
\hline
\end{tabular}

it was more efficient for employment generation. The major activities included in crops cultivation are land preparation, intercultural operations, weeding, etc., while the activities in cattle rearing included collecting green fodder, milking and selling of milk. An attempt was made to estimate the number of hired labour employed in farming and it was found that more number of hired labour are employed in cattle farming i.e. 174 mandays ha ${ }^{-1}$ year $^{-1}$.

\section{Conclusion}

The study has revealed that the cost of cultivation of crops was higher under dairy based farming system than under Jhum condition. But the latter was found to be more profitable and economically viable in the study area. This farming system has not only helped to increase farm income but also generated employment and led to sustainable farming. It is, thus, suggested to provide necessary support to make this system more adopted by the tribal people of Mizoram for its economic viability.

\section{Acknowledgement}

The authors acknowledge Director, ICAR-National Dairy Research Institute, Karnal-132001 (Haryana), India for providing financial assistance and infrastructure to carry out the research work. The first author also acknowledges the University Grants Commission for providing financial assistant during the entire period of the research work. They are also grateful to the anonymous referee for providing helpful suggestions.

\section{References}

Choudhury, A., 2004. Human-elephant conflicts in Northeast India. Human Dimensions of Wildlife 9, 261-270.

Government of Mizoram (GoM), 2013. State annual plan 2013-14. Department of Programme Planning and Implementation, Aizawl.

Kumaresan, A., Pathak, K.A., Bujarbaruah, K.M., Ngachan, S.V., Prabhakaran, P.P., Ramesh, T., Brajendra, 2008. Smallholder dairy production system in Mizoram: A multidimensional study. ICAR Research Complex for NEH Region, Umiam, Meghalaya.

Kumaresan, A., Prabhakaran, P.P., Bujarbaruah, K.M., Pathak, K.A., Chhetri, B., Ahmed, S.K., 2009. Reproductive performance of crossbred dairy cows reared under traditional low input production system in the eastern Himalayas. Tropical Animal Health and Production 41(1), 71-78.

Larka, N., Gauhara, A.K., Banafar, K.N.S., 2014. Economics of paddy production in Dantewada district of Chhasttisgarh. Trends in Biosciences 7(18), 2750-2754.

Mandal, R.K., 2011. Changing agricultural scenario and its impact on food habit in north east states of India. Food Biology 1(1), 14-21.

Michael Khoveio, L.L., Jain, D.K., Chauhan, A.K., 2012. Economics of milk production and its constraints in Nagaland. Indian Journal of Dairy Science 65(6), 520-526.

Navadkar, D.S., Amale, A.J., Gulave, C.M., Nannaware, 
V.M., 2012. Economics of production and marketing of Kharif maize in Ahmednagar district of Maharashtra state. Agricultural Situation in India LXIX(6), 309-316.

Patel, T., Karmakar, S., Sanjog, J., Surendra Kumar, Chowdhury, A., 2013. Socio-economic and environmental changes with transition from shifting to settled cultivation in North-Eastern India: An ergonomics perspective. International Journal of Agricultural Science and Research 3(2), 117-136.

Satapathy, K.K., Bujarbaruah, K.M., 2006. Slash and Burn agriculture: Its practice, effect and problem of development. In: Agroforestry in North East India: Opportunities and Challenges. ICAR Research Complex for NEH Region, 1-14.

Singh, K.R., Agarwal, S.B., 2007. Economics of milk production in Imphal west district of Manipur. Indian Journal of Dairy Science 60(6), 441-446.
Singh, K.R., Chauhan, A.K., 2015. Impact of dairy co-operatives on income and employment in rural Meghalaya. Indian Journal of Dairy Science 68(2), 173-179.

Singh, S., Dhillon S.S., 2015. Socio-economic analysis of ginger crop in Himachal Pradesh. Indian Journal of Hill Farming 28(1), 35-42.

Singh, S.P., Gangwar, B., Singh, M.P., 2009.Economics of farming systems in Uttar Pradesh. Agricultural Economics Research Review 22(1), 129-138.

Tripathi, R.S., Barik, S.K., 2003. Shifting cultivation in North East India. In: Bhatt, B.P., Bujarbaruah, K.M., Sharma, Y.P., Patiram (Ed.), Proc. Approaches for Increasing Agricultural Productivity in Hills and Mountain Ecosystem. ICAR Research Complex for NEH Region, Umiam, Meghalaya, 317-322. 